\title{
Microsatellite Marker C04107 as a Diagnostic Marker for Copper Toxicosis in the Danish Population of Bedlington Terriers
}

\author{
By H. F. Proschowsky ${ }^{1}$, B. Jepsen ${ }^{1}$, H. E. Jensen ${ }^{2}$, A. L. Jensen ${ }^{3}$, M. Fredholm ${ }^{1}$
}

${ }^{1}$ Division of Animal Genetics, Department of Animal Science and Health, ${ }^{2}$ Laboratory of Veterinary Pathology, Department of Pharmacology and Pathobiology and ${ }^{3}$ Central Laboratory, Department of Clinical Science, The Royal Veterinary and Agricultural University, Frederiksberg, Denmark.

\begin{abstract}
Proschowsky HF, Jepsen B, Jensen HE, Jensen AL and Fredholm M: Microsatellite marker C04107 as a diagnostic marker for copper toxicosis in the Danish population of Bedlington terriers. Acta vet. scand. 2000, 41, 345-350. - The linkage phase of marker C04107 was evaluated before implementation of the marker in a diagnostic test. Blood samples from 68 dogs were collected and genotyped by PCR. Two alleles were detected with sizes of $160 \mathrm{bp}$ and $164 \mathrm{bp}$ and allele frequencies of 0.45 and 0.55 respectively. Genotyping revealed that 35 dogs were heterozygous $(51.5 \%), 22$ dogs were homozygous for the normal allele $(32.3 \%)$ and 11 dogs were homozygous for the disease allele (16.2\%). Liver biopsies were taken from 14 selected dogs and the copper content was evaluated histologically. Biopsies from 8 dogs homozygous for the disease allele showed many copper granules along with single cell necrosis, haemosiderosis and cellular infiltration. In liver biopsies from 6 dogs genotyped to be heterozygous or homozygous for the normal allele, copper granules were absent or moderate in number and no lesions were present. The survey demonstrates that the linkage phase of marker C04107 in the Danish population of Bedlington terriers is similar to the linkage phase detected in other countries. Thus, the marker can be used in a diagnostic test for copper toxicosis in Denmark.
\end{abstract}

DNA-marker, liver disease.

\section{Introduction}

Copper toxicosis is a hereditary disease in Bedlington terriers, first described by Hardy and colleagues in 1975 (Hardy et al. 1975). It is an autosomal recessive trait (Johnson et al.1980) which is characterised by a reduced excretion of copper into the bile. Chronic hepatitis and cirrhosis develop as the amount of accumulated copper in the liver increases, usually leading to clinical signs of liver insufficiens in the middleaged dog (Twedt et al.1979). The accumulation of copper becomes histologically evident in liver biopsies at one year of age (Hardy 1975 et al., Twedt et al. 1979). Low copper diet and medical treatment to prevent further accumulation can be established and may prevent mortality due to hepatic failure (Brewer et al. 1992). An analogous condition called Wilson's disease exists in humans (Hardy et al. 1979, Su et al. 1982a), and for some time the diseases were regarded as equivalent. However, though similarities exist, the results of both linkage studies (Yuzbasiyan-Gurkan et al. 1993) and genetic mapping (van de Sluis et al. 1999) suggest that Wilson's disease in humans and copper toxicosis in Bedlington terriers have different biochemical and genetic backgrounds. 
Until recently, the copper content of liver biopsies has been the only way to detect copper toxicosis. This method is useful in order to point out individuals that will benefit from low copper diet or medical treatment but in regard to selection of breeding animals the method is inadequate since heterozygotes cannot be reliably discovered.

As demonstrated in many different mammalian species the identification of DNA microsatellite sequences and their use as genetic markers has provided a new diagnostic tool in regard to genetic disorders. The first systematic search for linkage with microsatellites in dogs was performed in Bedlington terriers with the aim of getting a marker for copper toxicosis (Yuzbasiyan-Gurkan et al. 1997). One marker, C04107, yielded a significant LOD score indicating linkage to the gene responsible for copper toxicosis. Two different alleles were observed in the marker locus: Allele 1 with a size of $163 \mathrm{bp}$ and allele 2 with a size of $167 \mathrm{bp}$. Allele 1 and 2 are linked to the normal allele and the copper toxicosis allele respectively. With marker $\mathrm{C} 04107$ it has been possible to distinguish between affected, normal and carrier dogs in the USA.

Since copper toxicosis is also a problem in the Bedlington terrier populations outside the USA, several investigations have been performed in order to verify the linkage relationship between the marker and the disease gene (Holmes et al. 1998, Rothuizen et al. 1999). This is a necessary precaution to take before a marker test is implemented in a new population. Similar clinical syndromes may have different genetic basis due to genetic heterogeneity and even if the underlying genetic defect is identical, there is always a risk that recombination events may have changed the linkage phase between the marker and the disease gene.

The marker C04107 has previously been evaluated in Bedlington terrier populations in Eng- land (Holmes et al. 1998) and in Germany, Belgium and The Netherlands (Rothuizen et al. 1999). In all countries allele 2 of the marker segregated with the disease gene as described in the USA indicating that the mutation was present in the original population of Bedlington terriers in England.

To our knowledge only one recombination event has been reported in a Bedlington terrier family in England (Holmes et al. 1998) resulting in linkage between allele 1 and the disease gene.

The present work presents the results of a survey of the use of microsatellite marker C04107 as a diagnostic marker in the Danish population of Bedlington terriers.

\section{Materials and methods \\ Animals}

The Danish population of Bedlington terriers comprises an estimated number of 100 adults producing an average of 3 litters per year.

A total of 68 EDTA-stabilized blood samples were collected from this population. The samples represented 39 females (57\%) and 29 males (43\%).

None of the dogs showed any signs of liver disease at the time of the blood sampling.

The dogs belonged to one big and one small family and their interrelations are illustrated in Fig. 1.

\section{Histology}

To determine the linkage phase in the 2 families liver biopsies were taken from 14 selected dogs (marked by an asterisk in Fig. 1). The biopsies were obtained percutaneously using a modified Menghini syringe. The biopsies were fixed in $10 \%$ buffered formalin, embedded in paraffin, and 4-6 mm sections were stained with haematoxylin and eosin (HE), Pearl's stain for iron, and rubeanic acid staining for copper (Thornburg et al. 1985). The content of copper 


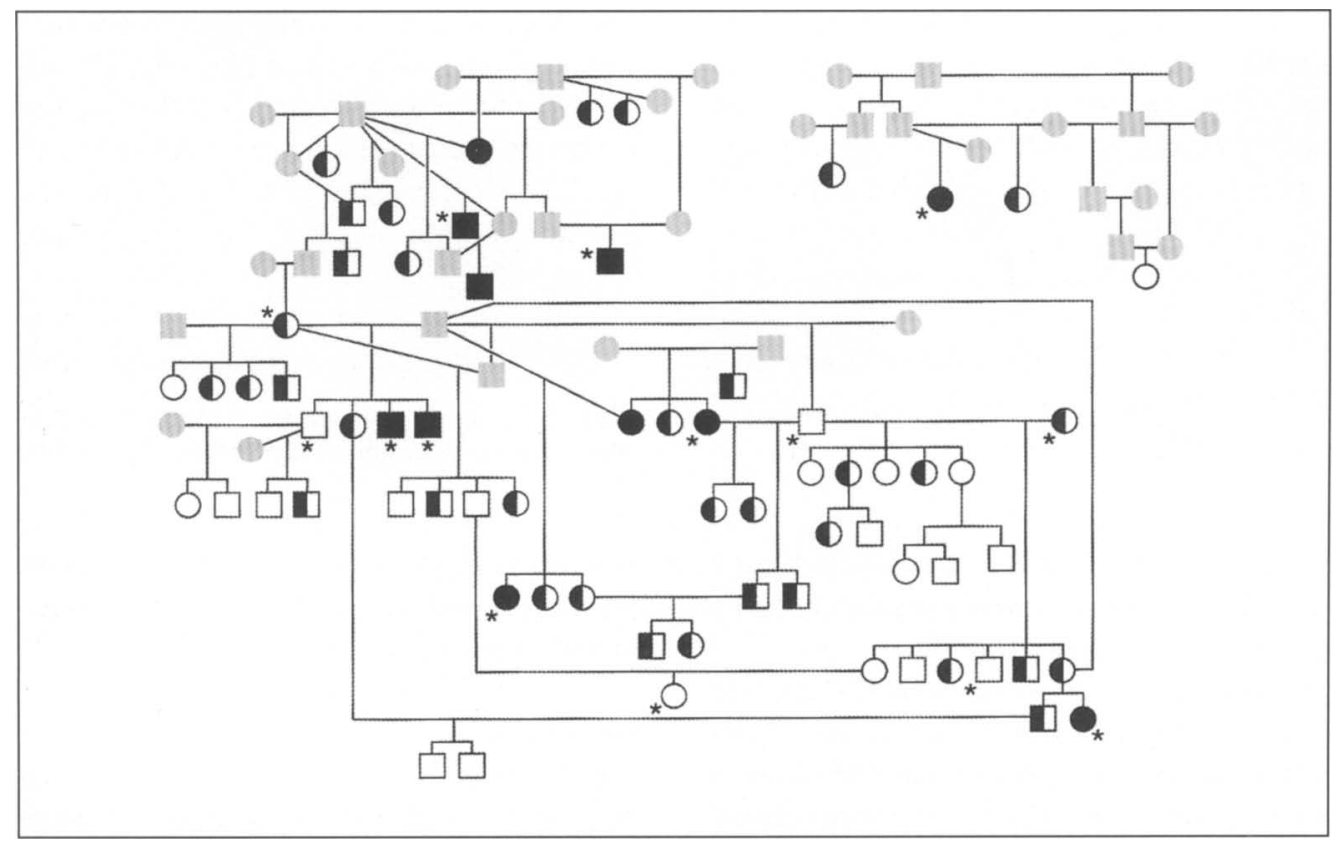

Figure 1. Pedigrees of the Bedlington terrier families. Grey symbols represent animals of unknown disease status included in the pedigrees to illustrate relatedness between the tested dogs. An asterisk marks animals from which liver biopsies are obtained.

was graded 0 to 5 according to the system adapted by Teske et al. (1992) in which dogs with grades 3 to 5 are considered to have copper toxicosis.

\section{PCR}

DNA was extracted using a salting-out protocol (Miller et al. 1988). The C04107 marker was genotyped using the primers described by $\mathrm{Yuz}$ basiyan-Gurkan and others (1997). Polymerase chain reaction (PCR) conditions were as follows: $50 \mathrm{ng}$ of genomic DNA as template in 2.5 $\mu 1$ PCR buffer, $1.5 \mathrm{mM} \mathrm{MgCl}, 0.04 \mathrm{M}$ dNTP, $0.3 \mu \mathrm{l}$ of each primer and $0.08 \mu \mathrm{l}$ Taq DNA polymerase. A touchdown PCR protocol was carried out at $2 \times\left(94^{\circ} \mathrm{C}\right.$ for $30 \mathrm{sec}, 66^{\circ} \mathrm{C}$ for 1 min and $72^{\circ} \mathrm{C}$ for $30 \mathrm{sec}$ ). The annealing temperature was then decreased by 2 degrees for 3 cycles $(\times 2)$. The next 35 cycles were $94^{\circ} \mathrm{C}$ for $30 \mathrm{sec}, 58^{\circ} \mathrm{C}$ for $1 \mathrm{~min}$ and $72^{\circ} \mathrm{C}$ for $5 \mathrm{~min}$.

Primer 2 was labelled with $\gamma^{32} \mathrm{P}$ and the PCR products were analysed on a $4 \%$ denaturing acrylamide gel. Alternatively fluorescent primers were used for the PCR amplification with subsequent analysis of the PCR products on an ABI 377 apparatus (Perkin Elmer).

\section{Results}

Genotyping of the 68 Bedlington terriers with microsatellite marker $\mathrm{C} 04107$ showed that 35 dogs were heterozygous $1 / 2(51.5 \%) ; 22$ dogs were homozygous $1 / 1(32.3 \%)$ and $11 \mathrm{dogs}$ were homozygous $2 / 2(16.2 \%)$. In our hands the sizes of allele 1 and 2 were $160 \mathrm{bp}$ and 164 bp respectively. The allele frequencies calculated on the basis of the unrelated dogs in the 


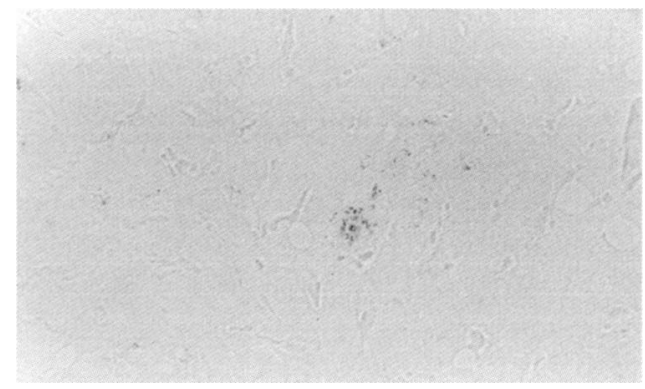

Figure 2. Incidental granules in solitary hepatocytes (grade 1).

pedigrees were 0.45 and 0.55 for allele 1 and 2 respectively and the Danish population had a calculated heterozygosity of 0.50 .

In the 8 biopsies from homozygous $2 / 2$ dogs the histological examination revealed many copper granules (grades 4 and 5) within hepatocytes throughout the liver (Fig. 4) along with necrosis of single cells, haemosiderosis and infiltration of inflammatory cells to a variable extend. In the heterozygous $1 / 2$ and homozygous $1 / 1$ dogs the graduation of copper granules was as follows: Absence, i.e. grade 0, in one dog; incidental granules in solitary hepatocytes, i.e. grade 1, in 2 dogs (Fig. 2); and small to moderate numbers of copper granules in small groups of hepatocytes, i.e. grade $2-3$, in 3 dogs (Fig. 3). In

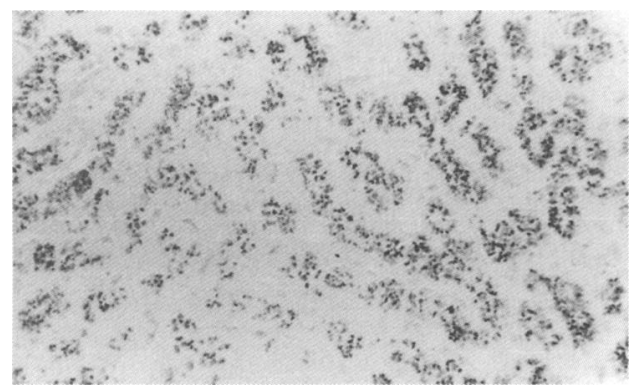

Figure 4. Biopsi from a homozygous $2 / 2$ showing many copper granules within hepatocytes througout the liver (grades 4-5).

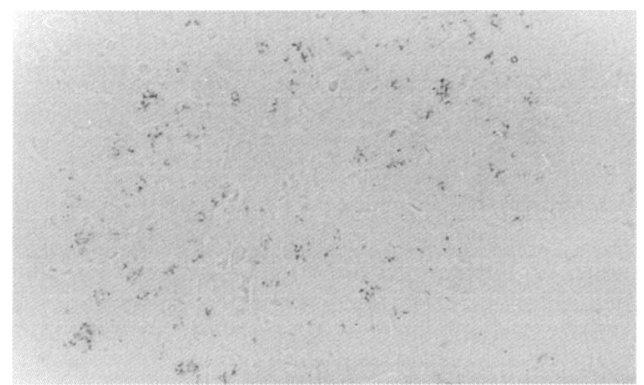

Figure 3. Small to moderate numbers of copper granules in small groups of hepatocytes (grade 2-3).

none of the dogs with grades of copper granules from 0 to 2-3 hepatocellular necrosis nor hepatitis was present.

\section{Discussion}

This survey reveals that the marker C04107 can be used in a diagnostic test for copper toxicosis in the Danish population of Bedlington terriers. The results of the genotypings are consistent with the liver biopsy results and the pedigree analysis performed. Our results are in accordance with findings in other populations and thus, they confirm the validity of the marker test. The surveys carried out so far all indicate that the genetic basis for the disease is similar all over Europe and in the USA. In the Danish population the frequency of allele 2 is 0.55 . In comparison the frequency is 0.57 in Belgium, while the frequency is lower in The Netherlands (0.33) and in Germany (0.31) (Rothuizen et al. 1998) and higher in the USA (0.78) (YuzbasianGurkan et al. 1997). It has been hypothesised that the low frequencies in The Netherlands and in Germany can be ascribed to the fact that a breeding policy based on liver biopsies was introduced 15-20 years ago in the population $(J$. Rothuizen et al. 1999).

Epidemiological techniques have been applied on the Dutch material, but no founder animal could be identified and the risk of the disease 
was quite evenly distributed over different familial clusters (Ubbink et al. 1998). Presumably, the mutation was already present in England before the spread of the Bedlington terrier breed to other countries.

The Danish Bedlington terrier breeding club has shown great interest in this new possibility to reduce the incidence of copper toxicosis. Thus, after January 1, 2000, offspring from Bedlington terriers can only be registered in the Danish Kennel Club when both parents are genotyped, and only homozygous healthy dogs are approved for breeding. Theoretically the disease allele will then be eliminated within a few generations, but care must be taken. Excluding the heterozygous carriers decreases the amount of animals available for breeding and in a numerically small breed like the Bedlington terrier this may lead to inbreeding and severe reduction of the genetic variability. To prevent this it can be necessary to include some of the heterozygous carriers for breeding. The genetic variability of the Danish population of Bedlington terriers is being evaluated at present.

The distance between the disease locus and the marker locus is not known but considering the recombination event described by Holmes \& coworkers (1998) other occasional recombination events must be expected. The marker test is therefore most reliable in families that have an affected dog available for determining the phase, i.e. which $\mathrm{C} 04107$ allele is linked to which allele at the copper toxicosis locus in this particular family. Ironically enough, an active breeding policy to eradicate the disease will make these affected animals more and more rare. In Denmark it has been arranged that liver biopsies can be taken from all genotyped Bedlington terriers when they are euthanised. The copper contents are measured and the results are compared to the genetic diagnoses. The procedure is without cost for the dog owner because the Danish Terrier Association pays the expenses. If a discrepancy occurs it will be possible to make further investigations to determine the linkage phase between marker and disease gene in this family.

Hopefully the mutation responsible for copper toxicosis will be identified so that a precise test will be available in the near future. Until then, the marker described by Yuzbasiyan-Gurkan \& others (1997) has to be considered the best tool that breeders of Bedlington terriers can use in the eradication of copper toxicosis.

\section{Acknowledgements}

The authors thank Jette Ellehauge and Camilla Ungermand for technical assistance and veterinarian C.S. Frederiksen for collecting blood samples in Jutland. We also thank the Danish breeders of Bedlington terriers for being helpful in all ways.

\section{References}

Brewer GJ, Dick RD, Schall W, Yuzbasian-Gurkan V, Mullaney TP, Pace C, Lindgren J, Thomas M, Padgett G: Use of zink acetate to treat copper toxicosis in dogs. Journal of the American Veterinary Medical Association 1992, 201, 564-568.

Hardy RM, Stevens JB, Stowe CM: Cronic progressive hepatitis in Bedlington terriers associated with elevated liver copper concentrations. Minnesota Veterinarian 1975, 15, 13-24.

Holmes NG, Herrtage ME, Ryder EJ, Binns MM: DNA marker C04107 for copper toxicosis in a population of Bedlington terriers in the United Kingdom. Veterinary Record 1998, 142, 351352.

Johnson GF, Sternlieb I, Twedt DC, Grushoff PS, Scheinberg IH: Inheritance of Copper Toxicosis in Bedlington Terriers. American Journal of Veterinary Research 1980, 41, 1865-1866.

Miller SA, Dykes DD, Polesky HF: A simple salting out procedure for extracting DNA from human nucleated cells. Nucleic Acids Research 1988, 16, 1215-1215.

Rothhuizen J, Ubbink GJ, van Zon P, Teske E, van den Ingh TSGAM, Yuzbasiyan-Gurkan V: Diagnostic value of a microsatellite DNA marker for copper toxicosis in West-European Bedlington terriers and incidence of the disease. Animal Genetics 1999, 30, 190-194. 
Su L, Ravanshad S, Owen CA, Jr, McCall JT, Zollman $P E$, Hardy RM: A comparison of copper loading disease in Bedlington terriers and Wilson's disease in humans. American Journal of Physiology 1982b, 243, G226-G230.

Teske E, Brinkhuis BGAM, Bode P, van den Ingh Th.SGAM, Rothuizen J: Cytological detection of copper for diagnosis of inherited copper toxicosis in Bedlington terriers. Veterinary Record 1992, 131, 30-32.

Thornburg LP, Beissenherz M, Dolan M and Raisbeck $M F$ : Histochemical demonstration of copper and copper-associated protein in the canine liver. Veterinary Pathology 1985, 22, 327-332.

Twedt DC, Sternlieb I, Gilderson SR: Clinical, morphologic, and chemical studies on copper toxicosis of Bedlington terriers. Journal of the American Veterinary Medical Association 1979, 175, 269-275.

Ubbink GJ, Van de Broek J, Hazewinkel HAW, Rothuizen J: Cluster analysis of the genetic heterogeneity and disease distributions in purebred dog populations. Veterinary Record 1998, 142, 209213.

Van de Sluis BJA, Breen M, Manoj N, Van Wolferen $M$, De Jong P, Binns MM, Pearson PL, Kuipers J, Rothuizen J, Cox DW, Wijmenga C, Van Oost BA: Genetic mapping of the copper toxicosis locus in Bedlington terriers to dog chromosome 10 , in a region syntenic to human chromosome region 2p13-p16. Human Molecular Genetics 1999, 8, 501-507.

Weber JL, May PE: Abundant Class of Human DNA Polymorphisms Which Can Be Typed Using the Polymerase Chain Reaction. American Journal of Human Genetics 1989, 44, 388-396.

Yuzbasiyan-Gurkan V, Blanton SH, Cao Y. Ferguson P, Li J, Venta PJ, Brewer GJ: Linkage of a microsatellite marker to the canine copper toxicosis lo- cus in Bedlington Terriers. American Journal of Veterinary Research 1997, 58, 1-5.

Yuzbasiyan-Gurkan $V$, Wagnitz S, Blanton SH, Brewer GJ: Linkage Studies of the Esterase D and Retinoblastoma Genes to Copper Toxicosis: A Model for Wilson Disease. Genomics 1993, $15,86-90$.

\section{Sammendrag \\ Mikrosatellit markør C04107 som diagnostisk mar- kør for kobber toxicose $i$ den danske population af Bedlington terriere.}

Koblingsfasen af markør C04107 blev evalueret forud for implementering af markøren i en diagnostisk test i Danmark. Blodprøver fra 68 hunde blev indsamlet og genotypet ved hjælp af PCR. Ved genotypningen fremkom to alleler med størrelser på henholdsvis $160 \mathrm{bp}$ og $164 \mathrm{bp}$ samt allelfrekvenser på henholdsvis $0.45 \mathrm{og} 0.55$. Genotypningen viste, at 35 hunde var heterozygote $(51.5 \%), 22$ hunde var homozygote for den raske allel $(32.3 \%)$, og 11 hunde var homozygote for den defekte allel $(16.2 \%)$. Leverbiopsier blev udtaget fra 14 udvalgte hunde, og kobberindholdet vurderet histologisk. I biopsier fra 8 hunde, der var homozygote for den defekte allel, sås mange kobberholdige granula, nekrose af enkelte celler, hæmosiderose og infiltration med inflammationsceller. I leverbiopsier fra 6 hunde, der var heterozygote eller homozygote for den raske allel, sås et varierende antal af kobbergranula fra ingen til et moderat antal og ingen læsioner. Undersøgelsen demonstrerer, at koblingsfasen mellem markør C04107 og sygdomsgenet er den samme i den danske Bedlington terrier population som i de øvrige undersøgte populationer i USA og Europa. Markøren er derfor anvendelig $\mathrm{i}$ en diagnostisk test for kobertoxicose $\mathrm{i}$ Danmark.

(Received August 16, 2000; accepted August 17, 2000).

Reprints may be obtained from: H. Friis Proschowsky, Department of Animal Science and Health, The Royal Veterinary and Agricultural University, Bülowsvej 13, DK-1870 Frederiksberg C, Denmark. E-mail: hfp@kvl.dk, tel: 352830 67, Fax: 35283042. 